\title{
Shaping of the systems of greenery in the districts of Lublin Cooperative Housing (LSM) in the context of planning and implementation of the project
}

\author{
Kamila Boguszewska \\ k.boguszewska@pollub.pl \\ Natalia Przesmycka \\ n.przesmycka@pollub.pl \\ Lublin University of Technology, Faculty of Civil Engineering and Architecture
}

\begin{abstract}
Collective Housing districts of Lublin Cooperative Housing (LSM) were the example of model multifamily developments of the second half of the twentieth century, conceptually designed by Roman Dylewski (architect and urban planner) in the years 1956-1977. They were built in the southern part of the city, on the hills cut by dry valleys and ravines, which significantly influenced the form of the buildings and the way of shaping the architectural and landscape enclosures.

The Housing district named after polish poet Adam Mickiewicz, designed by Felix Haczewski was based on the garden city concept. Famous visionary architect Oskar Hansen implemented his idea of a linear system and the principle of "absorbent background" into design of Juliusz Słowacki’s district. LSM housing districts were planned in detail, starting from the urban plan of the entire area, through architecture and meticulous arrangement of public spaces. Particular emphasis has been put on the nature of public and social activity spaces, as well as the surrounding greenery.

Various species of trees, shrubs and perennials were planted as a complementary element of social space in the district, which was also a part of the city's greenery system. Different elements of small architecture, such as: sculptures, ponds, and "rockeries" were placed there.

The article aims to characterize the principles of landscape and greenery design, as an inseparable element of LSM district and its current condition.

It is also interesting to study the transformation of the city sections deriving not only from the changing needs of users, but also from aesthetic preferences and the desire to follow a widely understood design trends.
\end{abstract}

Keywords: Lublin Cooperative Housing (LSM), systems of greenery, Rury Park.

\section{Introduction}

After the World War II, there has been a fast development of residential areas in Lublin as the response to the influx of people to the city within the realization of the six-year plan and because of lack of apartments, which followed this trend. Back then Lublin had one of the biggest density index in Poland - 2.4 persons per one room. Some of the first residential districts were created as early as in the 1950s thanks to the Zakład Osiedli Robotniczych ZOR (the Workers' Housing Development Administration). In that time, the following housing districts were built: ZOR Bronowice, ZOR Tatary I and ZOR "Zachód". They were built in the style of socialist realism, and they adopted the rule of the style of the architecture, which was traditional in style and socialist in content. Green areas dedicated to the residents were assigned to the regular quarters of residential buildings 
as their supplement. Currently, most of these green areas are used for parking areas inside the district. In most cases, housing districts had monofunctional character and were situated far from any service centers.

In 1955, Lublin had 131,500 residents, which gave the average index of 2.23 person per one room. In some quarters like Śródmieście, Czechów or Kalinowszczyzna, this index was much higher - 3 persons / room. Therefore, the decision was made to expand the area of the city - the residential areas in two directions - the north in Kalinowszczyzna and Czechów and the southwest in the area of so-called Rury ${ }^{1}$. These areas were devoted for multifamily districts of Lublin Cooperative Housing (LSM) and housing districts of one-family houses in Czuby and Węglin. Pre-war development of the area of current Nadbystrzycka street, called in the urban development plan "half-savage" was intended to be destroyed, or otherwise to be rebuilt and organized".

The quality of thinking about designing of residential districts started to change at the end of the 1950s, when the idea of collective housing districts had its return ${ }^{3}$. The new quality of architecture and urban planning of the residential complexes in Lublin was being introduced by Lublin Cooperative Housing (LSM), which was founded in $1957^{4}$.

Urban planning composition started to take into account such factors as topography, and the central parts of the districts were spared of high buidlings, and instead detached apartment houses of maximum four floors was planned. Special attention was put to planning and functioning of the public spaces and areas between the residential buildings, which were hierarchized and got diverse architectural form and "equipment" in the form of the architectural details designed individually for each of the new districts. The areas between the residential buildings were linked with the surrounding buildings (the residential complexes of the Adam Mickiewicz's district had direct entrances to the gardens between the buildings). The problem of communication and vehicular traffic was solved in an interesting way. In most of the districts, pedestrian traffic was separated from vehicular traffic with the use of interdistrict ring roads. The centres of residential districts were large common spaces dedicated to the users of diverse age groups. The green areas of the residential districts were joined with the green areas of the quarter thanks to the topography. It was possible, because 1957 was a kind of time frame, when it was possible to design for non-anonymous residents. A member of a housing collective, who paid the full price of their apartment, was someone different than a person who got their apartment as a gift, only because they were next in the line (...). ${ }^{5}$ The members of the collective housing were concerned not only about the future apartments, but also the entirety of their housing district. What is more, both in case of the oldest housing district-Adam Mickiewicz's district and more recent Juliusz Słowacki's district, the urban planners were cooperating with the future residents and space users as early as at the designing stage. There were surveys about functionality of the apartments especially made for the members of the housing cooperatives, where people could draw their ideas how to design their apartment ${ }^{6}$.

\section{The state of research}

The subject of post-war cooperative housing districts of LSM was very popular since the time that the first residential complexes were built. The history of their development and main functional - spatial assumptions were the professional interest of H. Gawaracki and C. Gawdzik (1964, 1974). Interesting materials about LSM were published by this asscociation as propaganda and promotional materials (5 years of Lublin Cooperative Housing LSM "Na stonecznym wzgórzu"), B. Dębiniec - Kalinowska (1968), (Nowy Lublin Osiedla LSM - New

1 "Rury" residential quarter was built in the area of former agricultural fields in the south-west part of Lublin. Most of the area belonged to monasteries (Rury Jezuickie, Bonifraterskie).

2 Ogólny Plan Zagospodarowania Przestrzennego Miasta Lublina (General Spatial Development Plan of Lublin), 1956-1965, D III - housing, C14, the archive of the Lublin Town Hall.

3 Collective housing districts in Lublin were built as early as during inter-war period.

4 D. Kociuba, Lublin, Rozwój Przestrzenny i funkcjonalny od średniowiecza do wspótczesności, Wydawnictwo Adam Marszałek, Toruń 2011, p. 282-283.

5 Materials 1957-1967, 8/6, I/6, F. Haczewski, Zasady projektowania osiedla im. Adama Mickiewicza w Lublinie, the archive of Lublin Housing Collective LSM, after: I. Pastuszko, Nowoczesne planowanie przestrzenne na przykładzie planu ogólnego rozwoju Lublina, in Annales Universitatis Mariae Curie - Skłodowska, Lublin - Polonia, sectio L, vol. XV, 2, 2017, p. 73.

6 H. Dąbkowski, R. Karaś, Lubelska Spółdzielnia Mieszkaniowa, Edition; Centrala Rolnicza Spółdzielni „Samopomoc Chłopska”, Zakład Wydawnictw 1968, p. 43. 
Lublin of LSM district, 1968), L. Gnot (1987). The changes of the area of the districts of LSM were researched by E. Przesmycka and M. Sosnowska $(2007,2010,2013)$. The way to shape the public space in cooperative housing districts was also the interest of N. Przesmycka and M. Dmitruk (2017), and participation model of planning of a residential complex - I. Pastuszko (2017). The publications of one of the planners of the Juliusz Słowacki's district - Oskar Hansen are separate category. The assumptions made in his plans - the idea of linear continuous system and the idea of the open form were the important chapter of Polish and international urban planning development of the second half of the 20th century. He described himself the main concept of his works in professional journals, eg. Architektura $(1959,1960,1966)$. Uncompromising works of Oskar Hansen were described in a comprehensive monography edited by J. Gola (2005). The rules of creating Rury quarter were appreciated in Poland and abroad. They were mentioned as a perfect example of the post-war modernism districts, which was the subject of research of international group of students and staff of Massachusetts University of Technology Special Interests Group of Urban Settelments (SIGUS), Center for Envirenmontal Development and Planning (CENDEP) of Oxford Brookes University and the faculty of Architecture of the Warsaw University of Technology. The result of this study was the publication of D. Abramson (1992) focusing on an attempt to work out the new, alternative (to the planned one) centre of LSM using the method of participation planning. The unseparable element of the districts of Rury was greenery, which was the subject of the research of the Univeristy of Life Sciences and Lublin Catholic University (KUL). The tree stands and greenery of the districts of Lublin Housing Cooperative LSM including creating of the urban parks as the form of protection of the Lublin ravines were the subject of the articles of E. Trzaskowska and M. Adamiec (2014), (2015). This issue was raised also in the new multiauthor monograph presenting diverse outlooks and opinions of Lublin's academics on the potential and dangers of the ravines and dry valleys of Lublin (2014).

\section{Ecological system of protected areas of Lublin city}

Ecological system of protected areas of Lublin city (ESOCH) was the part of the Local Spatial Development Plan of Lublin of 1986. It was supposed to be "an active spatial layout interconnecting protected areas". This layout was designed as "open form" consisting of the structure made of natural ecological systems, open areas of Lublin city merged with external ecological systems. The whole system was hierarchized: starting from river valleys and valley depressions, which were the basis of the cohesion of the system, which merges basic structural entities with the field and forest areas7. Important functional areas in the whole system were Zemborzycki Resevoir, Stary Gaj forest and Dąbrowa forest, which create Czerniejewski Protected Area ${ }^{8}$ in the south-west part of Lublin and "Baczki" functional area on the north of the ESOCH system. The key role in the whole system belongs to so-called "ecological nodes", of which most important are the estuaries of Czerniejówka and Czechówka to Bystrzyca river in the centre of Lublin, in the place of Staw Królewski (Królewski pond) in the past, which now is settled by alottments (Rodzinne Ogródki Działkowe) ${ }^{9}$. The important areas called in the plan "the link of the ecosystem" were municipal parks, didactic greenery (botanical garden) and forest parks. In the area of the districts of LSM, the bases of the systems were ravines and valleys being the links to above-mentioned river valleys of Bystrzyca, Czerniejówka and Czechówka as the "active biological ecosystems". ${ }^{10}$ Their extension was the greenery of the dry valley, which was supposed to be the quarter park in the urban development plan

7 Local Plan of General Spatial Development Plan of Lublin - the text of the plan, 1986, p. 5

8 M. Żurkowska, Planowanie przestrzenne jako instrument ochrony systemu przyrodniczego dolin rzecznych $i$ suchych dolin w Lublinie, in: Wąwozy i suche doliny Lublina potencjat i zagrożenia, pod redakcją Ewy Trzaskowskiej, Lublin, 2014, p. 16

9 The allotments (Rodzinne Ogródki Działkowe) at the place of the former pond (Staw Królewski) are "Robotnik" and "Młynarz" allotments of 2.71 and 7 hectares respectively. These allotments were made in the 2 nd half of the 20th century and were dedicated for the use of 192 families. The biggest and oldest allotment complex was made shortly after the 2nd World War (1948) at the place of the former pond (Staw Królewski). The Podzamcze allotments ("Rodzinny Ogród Działkowy Podzamcze") of 34 hectares were used by 571 families; after: Działkowcy nie chca oddać ogródków działkowych pod wielki staw. Maja rację? http://lublin.wyborcza.pl/lublin/1,48724,21010782,dzialko wcy-nie-chca-oddac-ogrodkow-pod-wielki-staw-maja-racje.html, accessed 10.10.2018, in: Gazeta wyborcza, 22 November 2016, and: M. Żurkowska, Planowanie przestrzenne jako..., p. 16.

10 Local Plan of General Spatial Development Plan of Lublin, 1986, p. 11-13. 
of the districts of Lublin Housing Collective LSM. Currently it functions as the Rury quarter park localized on the area of the one of 84 ravines and dry valleys ${ }^{11}$ in Lublin (Fig. 1).

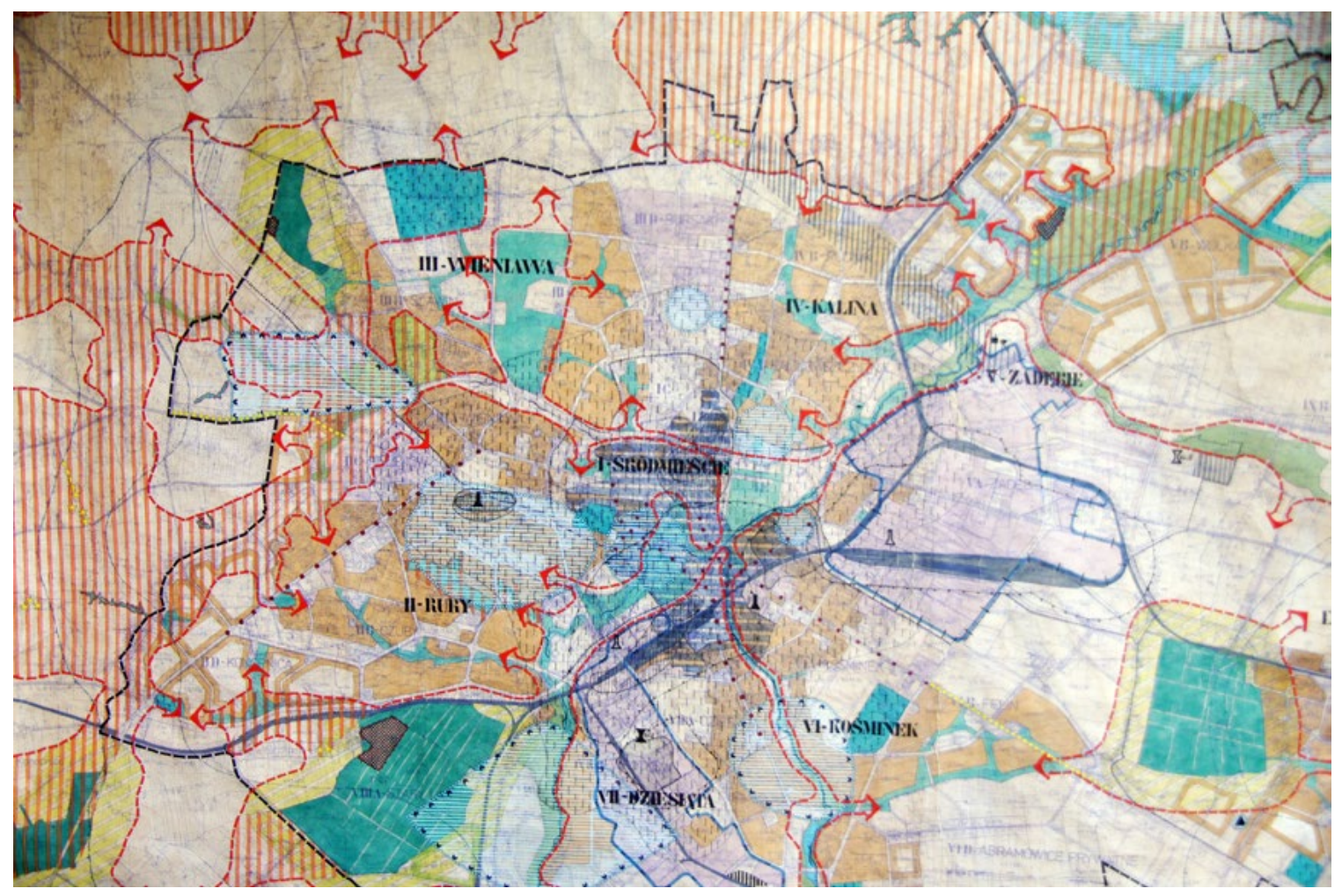

Fig. 1. Lublin Urban Complex, nature 1985, the Archive of the Lublin Town Hall

\section{Lublin Housing Collective LSM - the districts - urban development plan}

The districts of Lublin Housing Collective LSM were planned in south - west part of Lublin on the south of Głęboka Street. Historically, this area was called "Rury" and was used for agriculture. In the past, it was a field used mainly for horticulture and orchards in the individual parcels. According to the guidelines of plan, this area was to be divided and used for the needs of detached housing complex. That is why it was the unimproved area, poorly communicated with the city. After the change of general urban development plan of Lublin in 1957 and introduction of the passage about the location of the multi-storey residential districts in the area of Rury quarter, as of 17 April 1958, the new district got general location of $46 / 58$ and the permission to build the area of the surface of 30.25 ha. Detailed location was obtained one and a half year later (17/07/1959) ${ }^{12}$. At first, the area of the first district was forecasted on the parcel of the surface of 42 ha (Adam Mickiewicz's district). In the general development plan, the area of "sunny hills" were supposed to be an alternative to the parcels along Lipowa Street, which were to constitute the new area of the city of Lublin in the first development plan devoted to the residential buildings ${ }^{13}$.

The borders of the Rury quarter are from the south - the Rury ravine - quarter park, from the north - Gleboka, Nadbystrzycka and Plazowa Street, from the south - Bystrzyca River and Nadbystrzycka Street and from

11 M. Trzaskowska, in: Wąwozy i suche doliny Lublina potencjat i zagrożenia, editor: Ewa Trzaskowska, Lublin, 2014

12 H. Dąbkowski, R. Karaś, Lubelska Spółdzielnia Mieszkaniowa, Ed.; Centrala Rolnicza Spółdzielni „Samopomoc Chłopska”. Zakład Wydawnictw., 1968, p. 29

13 M. Szlachetka, Jak budowała się dzielnica LSM "Panie Inżynierze to sa przecież góry", in: Kurier Lubelski, https://plus.kurierlubelski.pl/jakbudowala-sie-dzielnica-Ism-panie-inzynierze-to-sa-przeciez-gory/, accessed 10.10.2018 
the west - Armii Krajowej Street, Bohaterów Monte Cassino Street and further in the direction of Krasińskiego Street, Zana Street, Balladyny Street in the direction of Głęboka Street ${ }^{14}$.

The characteristic feature of this part of the city is diverse topography and the system of dry valleys and ravines, which now is the basis of Ecological system of protected areas of Lublin city (ESOCH). The concept of the districts was prepared by Lubelska Pracownia Urbanistyczna (Lublin Urban Development Office) led these days by architect and planner Romuald Dylewski ${ }^{15}$ between 1956 and 1974. According to him: Every element of topography was drawn very carefully and accurately. The main assumption was that residential buildings will be built on the hills and ravines and dry valleys will be used for roads and greenery. ${ }^{16}$ Construction of the residential buildings being the part of the complex, which is currently located in the surface of 242 hectares started in the 1950s. The first to build was Adam Mickiewicz's district (1959), then Juliusz Słowacki's district (1964 - 1972), Piastowskie district, Krasiński's district (1971), Sienkiewicz's district (1973) Konopnicka's district (1974) and at the end Bolesław Prus's district (1975). ${ }^{17}$ (Fig. 2)

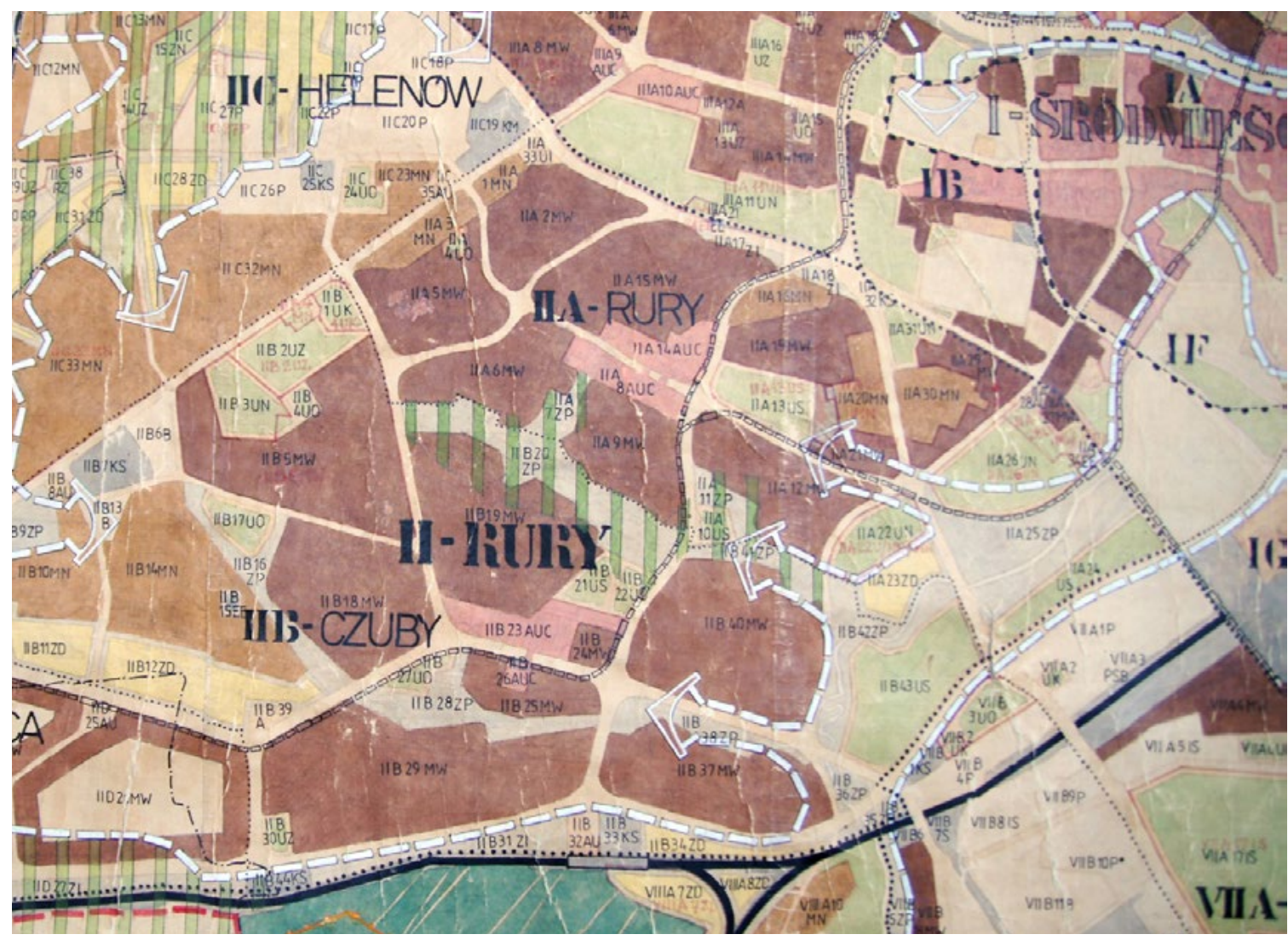

Fig. 2. Lublin Urban Planning Team, Spatial Development Plan, 1:100000, the fragment of the plan (the Archive of the Lublin Town Hall).

The districts of LSM were designed by many outstanding architects like engineer architect Feliks Haczewski (designer of Adam Mickiewicz's district and general, not implemented concept of the residential complex of LSM from 1960) or Zofia and Oskar Hansen responsible for architectural plan of Juliusz Słowacki's district being

\footnotetext{
14 The Act no. 627/XXIX/2009, of the Lublin City Council of 19 February 2009 regarding the status of Rury quarter.

15 M. Szlachetka, Jak budowata się..., op. cit.

16 Ibid.

17 N. Przesmycka, M. Dmitruk, Rewitalizacja przestrzeni międzyblokowych inicjatywa społeczna w procesie rewitalizacji na przykładzie wybranych przestrzeni w Lublinie, typescript, p. 286. Adam Mickiewicz's district has a surface of 24.32 hectares, Juliusz Słowacki's district, Maria Konopnicka's district -17.20 hectares, Zygmunt Krasiński's district -14 hectares, Piastowski district -10.71 hectares, Prus' district -22 hectares and Henryk Sienkiewicz's district - 12.5 hectares.
} 
the materialization of the linear continuous system and the idea of open form in the scale of the district. Antoni Herman was responsible for the development plan and architecture of residential districts of Piastowskie district $^{18}$ and Maria Konopnicka's district and for Henryk Sienkiewicz's district and Zygmunt Krasiński's district - engineer architect Janusz Link.

The typical feature of these districts was detached residential block buildings characteristic for new built residential districts of post-war modernism, which was an attempt to realize the assumptions of the Charter of Athens ${ }^{19}$ and to solve the post-war problem of lack of apartments in Lublin.

Residential districts were accompanied with the full program of basic services in the scope of culture, education, commerce, gastronomy, artisan services, communication and health ${ }^{20}$. The best example is Adam Mickiewicz's district planned in a way that the buildings with services were not farther than 150 meters from residential buildings ${ }^{21}$.

Adam Mickiewicz's district is the oldest district made by the housing cooperative LSM. It was planned as a garden district. Its designer and dowser - Feliks Haczewski got the price of 2nd degree (KBUA) for the urban development plan of this district. It is located between Głęboka, Wileńska, Filaretów and Zana Street. Głęboka Street was built for the anniversary of 15 years of Polish People's Republic. It joined Kraśnicka Road with Sowińskiego Street (the start of the construction was in 1959). This route has improved greatly the communication of LSM districts with central quarter of Śródmieście. ${ }^{22}$

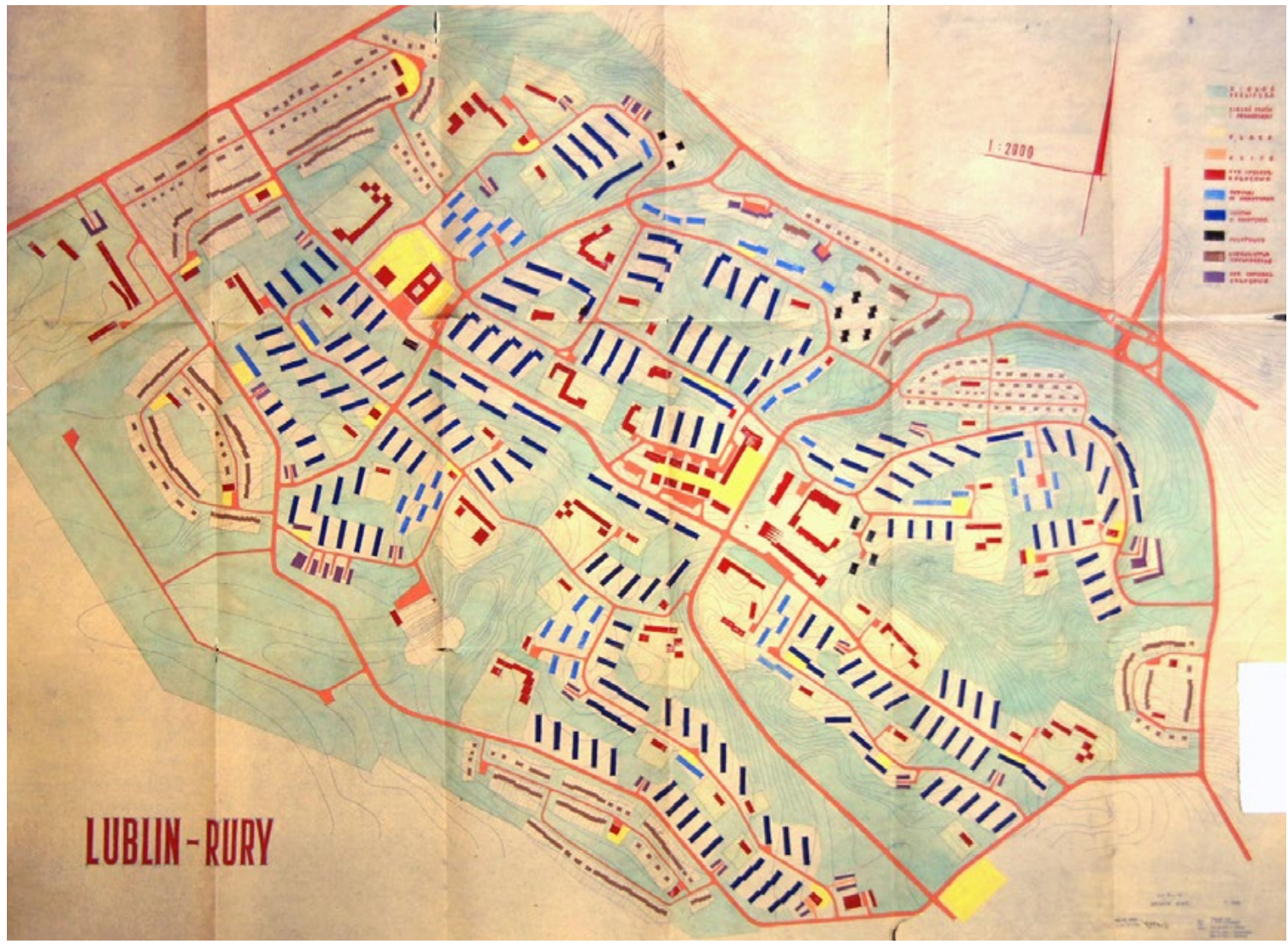

Fig. 3. General development plan of the LSM of eng. arch. Feliks Haczewski of 1960, the Archive of the Lublin Town Hall 
The streets followed the shape of the ravines. The characteristic feature was that the material solutions and standard of apartments was much better than in the districts that were built later within the framework of LSM investments. Later norms and standards fixed much higher population density (from 330 people / hectare to 660 people / hectare).

The first concept of the residential district prepared by Feliks Haczewski in 1960 included the central part of the district as public space used for greenery. From the north, south and west, four-storey residential buildings were indicating the inside of the square and from the north on the other side of the internal street, just like on the east side, lower, three-storey housing development. The district contained also evenly spaced service - social buildings: schools, health center, service pavilions, centre for culture. Urban accent was four buildings in the north-east part of the complex (Fig. 3).

\section{Shaping of the green areas in the districts of LSM}

The area of Adam Mickiewicz's district was realized on the surface of 42 hectares, 20 of which were used for greenery and recreation. It means that for every resident, it was $20 \mathrm{~m} 2$ of the green area.

The oldest district of Lublin Housing Collective LSM had the annual tradition of planting the trees. About 1485 deciduous trees, 1030 deciduous bushes and 345 coniferous trees and bushes were planted in Adam Mickiewicz's district during the period of two years ${ }^{23}$. From the very beginning (the end of 1950) the public areas of the districts have been made by the residents themselves as a part of community service. The plasters were still wet on the freshly erected buildings, when the constructors together with residents started to organize the surroundings, make the lawns, plant the trees and bushes. After two years the district started to look like neat garden, and the care of administration and residents made it flourish.24

At first, the residents were responsible for organizing of the space and conservation of greenery. With time, the most duties were taken over by the landscape service equipped with professional tools ${ }^{25}$. This service was later called zakład zieleni (entreprise for urban greenery).

It was not true that community service was in this case the set of chaotic actions. The greenery planted by the residents was well-thought in terms of their species and provenance. The garden complex was managed by its planner - eng. Józef Maciejewski, who was also responsible for the Park Ludowy ${ }^{26}$. As for the species planted in the district, the most common ones were native limes, popplars, oaks, beeches, birches, willows, maple trees and spruces.

The biggest decoration of the district is its marvelous greenery. The plan is closed by the course of four main streets - this is the perfect example how to organize green areas. What we have here... Graceful beeches creating green wall against the noise and metropolitan air pollution, old weeping willows, bushes and dwarf trees as the middle part of the greenery and also beautifully maintained lawns, many diverse flower beds planned in a way that no matter if it's earliest spring or latest days of autumn - it's always flowery and colorful. The plan is completed by stony alpine gardens and pond with a fountain with fishes fed by most residents. Benches along the pedestrian lanes are occupied by the elderly and mothers with children. Children can use many playgrounds. One of them has even the small model of space rocket, plane with turning propel and real but immovable car27.

The greenery designed and planted in Adam Mickiewicz's district was not appreciated by central authorities, despite the fact that at the beginning it was assumed that all districts realized within Lublin Housing Collective LSM would have the similar proportion of greenery per capita. The fact that in the central part of the district was a playground so big that it could be used for a couple of additional apartment blocks was also controversial. Maintained iconography and aerial photos made at the beginning of the 1980s prove that

\footnotetext{
23 Nowy Lublin Osiedla LSM, Lubelska Spółdzielnia Mieszkaniowa, Wojewódzki Ośrodek Informacji Turystycznej w Lublinie, Lublin, 1977, p.33-34

24 Ibidem., p. 8

25 H. Dąbkowski, R. Karaś, Lubelska Spółdzielnia Mieszkaniowa, op. cit., 61,

26 Ibid., s. 61

27 Nowy Lublin Osiedla LSM, Lubelska Spółdzielnia Mieszkaniowa, Wojewódzki Ośrodek Informacji Turystycznej w Lublinie, Lublin, 1977, p. 10
} 
Adam Mickiewicz's district had significant ratio of high greenery ${ }^{28}$. Other districts of LSM that were built later, together with Juliusz Słowacki's district, the construction of which was partly overlapping with the construction of Adam Mickiewicz's district, have much less greenery. According to the documentation in the form of dendrochronology inventory of the district from 1992, it was as much as 4200 trees on the area of the Adam Mickiewicz's district. ${ }^{29}$ The landscape plan of Juliusz Słowacki's district was made by Wanda Staniewicz. The system of greenery introduced into the area of the district was supposed to mention the idea of open form of Oskar Hansen and together with planned infrastructure - centre for culture, kindergarten, market etc. was supposed to be Hansen's "absorptive background" - the space of life. (Fig. 4A, 4B).
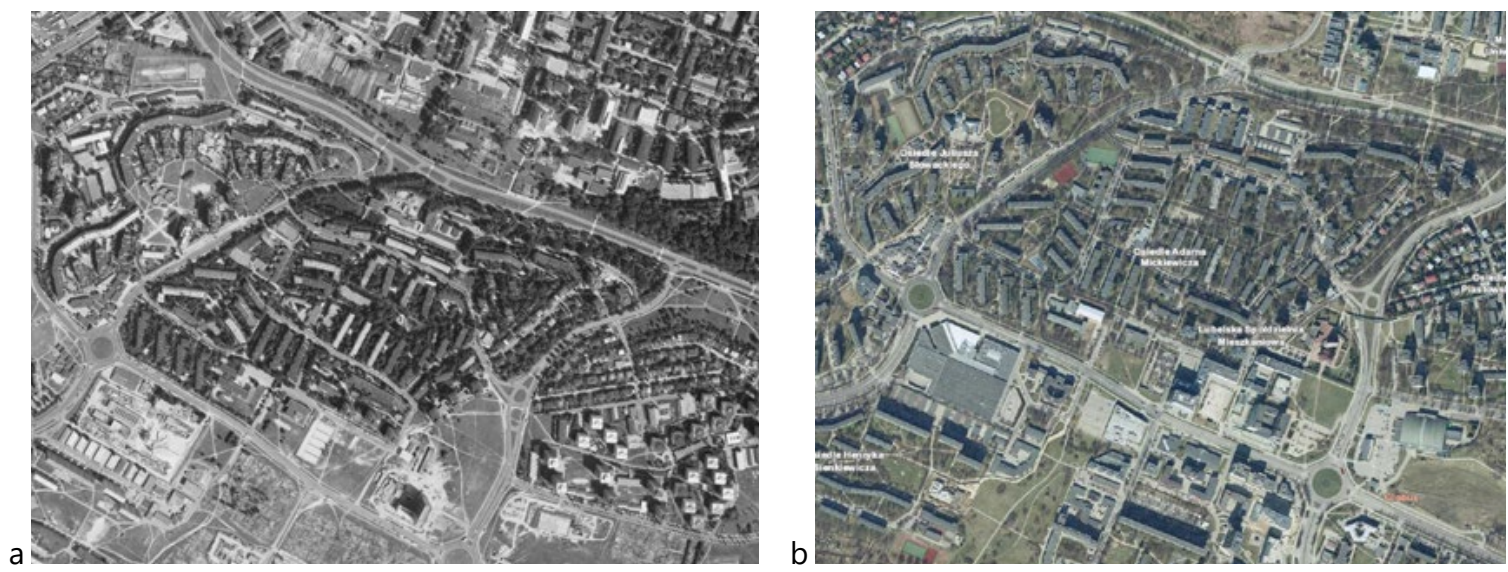

Fig. 4. A: The 1980s, the aerial photography of LSM, the archive of KAUiPP, Lublin University of Technology, Picture B: Current shape, Source: geoportal, accessed 10.10.2018
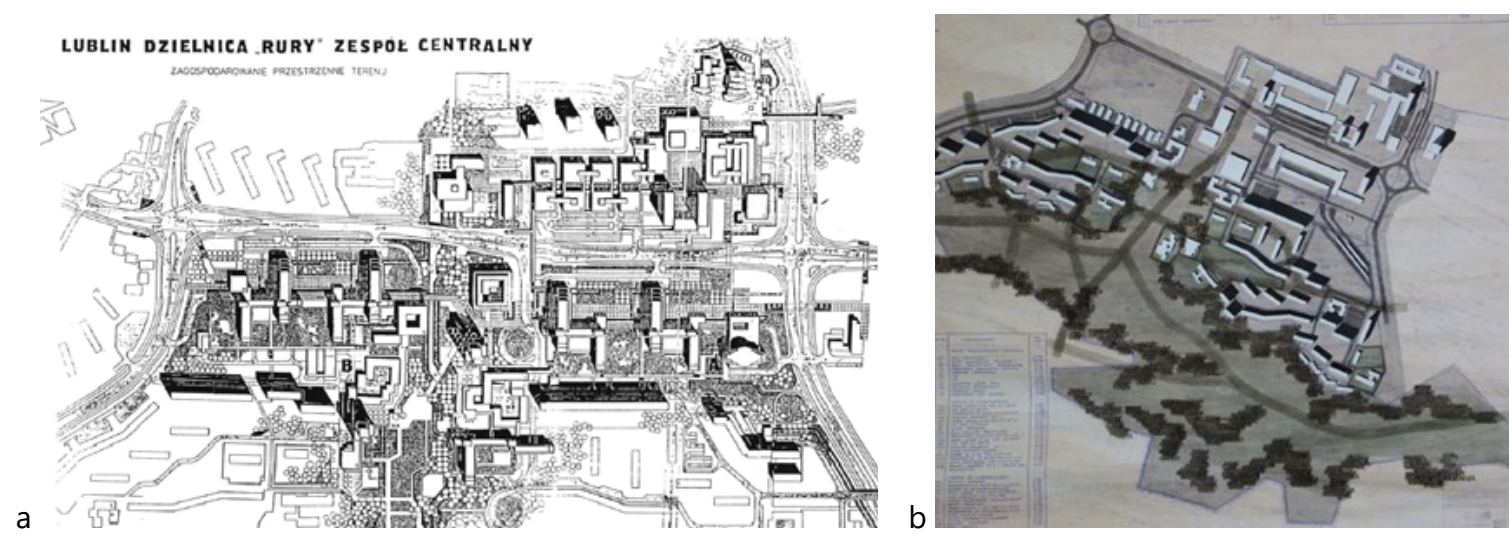

Fig. 5. A - Lublin, Rury quarter, the central complex, spatial development plan (the Archive of the Lublin Town Hall), Lublin, B - Composition plate, Detailed spatial development plan of the second part of the Rury district of LSM - districts: $\mathrm{H}$. Sienkiewicz's district and M. Konopnicka's district in Lublin.

28 M. Szlachetka, Jak budowała się..., op. cit. In this article, eng. arch. Romuald Dylewski said that Stanisław Kukuryka, president at that time, was defending fiercely functional - spatial assumptions adopted by the planners and designed infrastructure, and due to that it was possible to force through the plan despite the defiance of central government with Julian Tokarski, the deputy prime minister at that time.

29 E. Przesmycka, M. Sosnowska, Przeobrażenia układów zieleni osiedlowej na przykładzie zespołu im. Adama Mickiewicza Lubelskiej spółdzieln Mieszkaniowej, Czasopismo Techniczne, p. 73 
Table 1. Table on the basis of the data from LSM materials, own elaboration of the author

\begin{tabular}{|c|c|c|}
\hline $\begin{array}{l}\text { Name of } \\
\text { the district }\end{array}$ & $\begin{array}{c}\text { Period of } \\
\text { construction }\end{array}$ & Architect \\
\hline $\begin{array}{c}\text { Adam } \\
\text { Mickiewicz's } \\
\text { district }\end{array}$ & 1958-1969 & $\begin{array}{c}\text { Arch. Feliks } \\
\text { Haczewski, } \\
\text { greenery, } \\
\text { eng. Maciejewsk }\end{array}$ \\
\hline
\end{tabular}

Juliusz

Słowacki's $1964-1972$ district

Piastowskie
district

Zygmunt

Krasiński's

district

Henryk

Sienkiewicz's

district

1973

Janusz Link

Ezuebiusz Maj

Janusz Link

Tadeusz Bobek

Euzebiusz Maj

Arch. Zofia and

Oskar Hansen,

greenery

eng. Wanda

Staniewicz

Antoni Herman

Kumelowski

1970-1975
58 residential buildings, 3107 apartments,

46 public utility buildings (kindergarten, two schools, culture centre, health centre, service pavilions)

18 residential buildings, 1957 apartments, 7290 - residents, gross population density index 449 residents/ ha, sculpture of Kazimierz Stasz

30 residential buildings, 1314 apartments, 4 buildings for commerce and services, sculptures of Barbara Zbrożyna, Ryszard Lis, Marian Swist, Lech Kunka, Tadeusz Huszczo

17 residential buildings, 1294 apartments, sculpture of Pegaz of Jan Borowczak

14 ha 7.64 ha

8.6 ha it borders from the north with the quarter park

22 multi-family buildings (19 designed by Janusz Link architectural team of arch. Euzebiusz Maj
24.34 ha 12 ha

16.2 ha 10 ha

6 ha it borders from the 17.20 ha north with the
The surface The surface of the of the green district [ha] areas [ha] quarter park

11.5 ha it borders from the north with the quarter park 


\section{LUBLIN DZIELNICA ..RURY“ ZESPOE CENTRALNY}

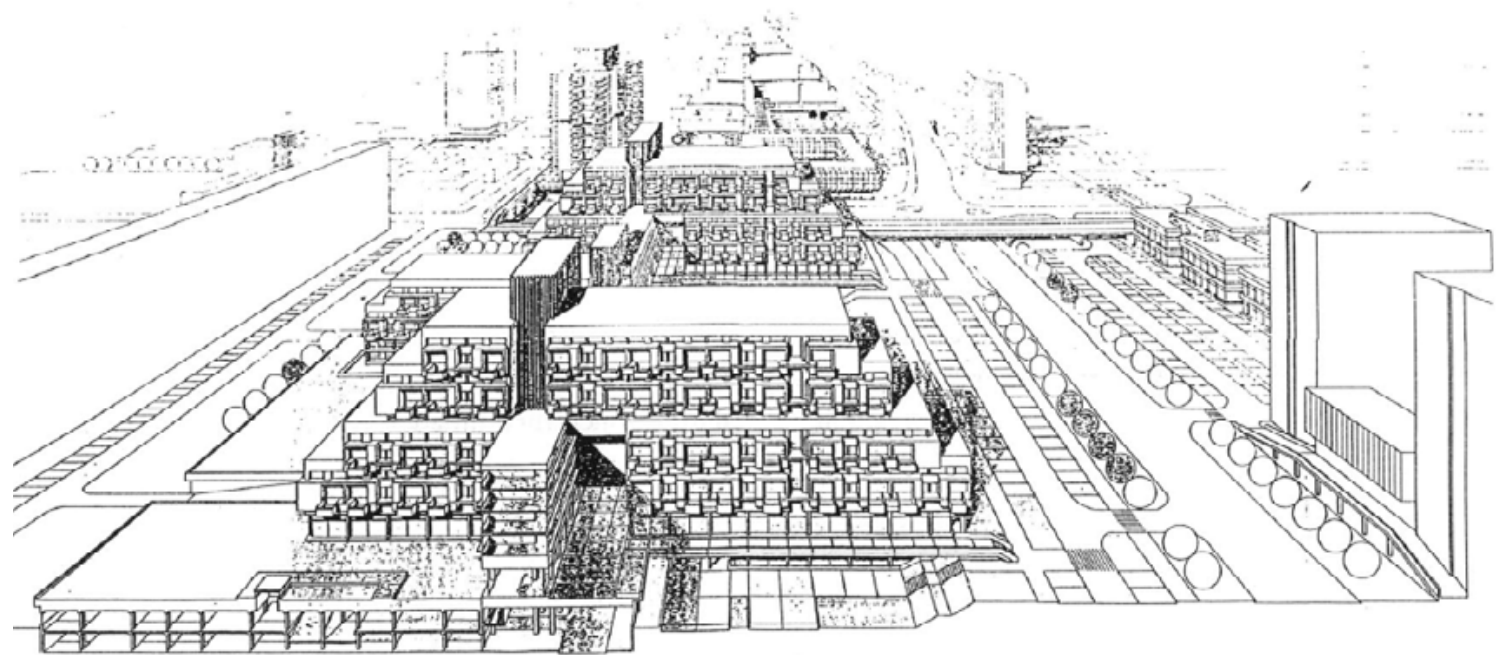

Fig. 6. Lublin. Rury quarter, the central complex, spatial development plan (the Archive of the Lublin Town Hall), Lublin.

In the districts of LSM, the greenery was not only used for recreation, but also for services. The general development plan of Rury quarter was not implemented as the whole.

The Rury quarter comprised of seven housing districts. In the part of the complex along Zana Street which separated the whole residential area into the two parts, the area was reserved for the realization of the Central Complex divided into four program - functional complexes in the form of commerce - service - administration centres localized in the north part of the development ${ }^{30}$, centre for culture in the form of the existing cultural centre extended by the district's library, recreation garden joining two parts of the urban development complex - with the use of topography and physiography of the area and non-intrusive industry factories. The development plan was implemented only in marginal scope, because only the buildings of the planning office and the Roman-catholic church were built. (Fig. 5A, 6)

\section{The principles of shaping of the greenery of Rury residential quarter in Lublin}

The principles of shaping of the greenery of Rury residential quarter in Lublin were defined in the General Development Plan of Lublin approved in 1959 and made by City Urban Planning Office. According to the plan, the complex of greenery was to be created, which fulfills the needs of everyday passive recreation (infrastructure such as pedestrian lanes and benches) and active recreation (infrastructure such as allotments and sport equipment) of the residents. Greenery in this plan was also supposed to be health-oriented - through creating of characteristic microclimate and winding of the city. It was supposed to isolate the district from the intrusive areas, noise and air pollution. The basis of shaping the system of greenery in the city scale was three river valleys - of Bystrzyca, Czechówka and Czerniejówka, which together with the system of planned parks were supposed to create "the network of organized greenery linked with building bands which create green entrances to the parks". ${ }^{31}$ According to the development plan, the green areas together with quarter parks on the surface of 201 hectares $^{32}$ were to be created, which would give the ratio of $8 \mathrm{~m}^{2}$ of the greenery for one resident and

30 Planned buildings were a cinema, a gastronomic complex, a department store, a passage of commercial-service pavilions megasm, police station, after: B. Jezierski, Zespót centralny dzielnicy Rury, in: Miesięcznik Osiedle, gmina, region, kraj, Miasto 88, 9/ September, p. 10.

31 Urban Planning Office M. Z. A. B. in Lublin, General Urban Spatial Development Plan of Lublin, Lublin 1957, VII Greenery and sport, C 56, C 59, C 60

32 Planned investments in greenery were founding of Ludowy Park (50 ha), Śródmiejski Park (10 ha), Kultury Park (90 ha). 
would increase significantly from the former $1.1 \mathrm{~m}^{2}$ of the greenery surface and $0.9 \mathrm{~m} 2$ of the sport infrastructure surface. The additional elements to the green networks of the parks were greenstones and squares of total surface of 50 hectares. These areas were dedicated for mothers with children and situated not more than 10 minutes walking distance from the places for passive rest (eg. benches). ${ }^{33}$

The plan envisaged the ratio of $2 \mathrm{~m}^{2}$ of this type of areas for one resident. The local spatial development plan of the second Rury quarter of LSM from 1969-1971 provided for the detailed guidelines for shaping of the landscape and greenery of the south districts of LSM quarter which border with planned quarter park. The basis was to protect existing landscape and topography of the area taking into account its characteristic features including native flora.

Planned buildings were supposed to be subject of zoning with the regard to their height, and grouping - zoning in case of medium-height buildings. Functional - spatial plan was created in a similar way; the principle that was used was the principle of internal organization of a structural entity with concentration of the related program groups. Next problem that was taken into account was the way of creating of communication tracts depending on external public transport, connections of individual residential entities and the system of greenery, which created the green infrastructure of the districts of LSM. The basis of this "green network" was supposed to be the quarter park, so-called South Park. The main planner of this complex was architect Janusz Link, and of greenery - Euzebiusz Maj. ${ }^{34}$ (Fig. 5 B)

The Rury Quarter Park was planned in the south part of the residential complex of LSM. Its location was determined by the topography of the area in the form of the dry valley, which was the border of Rury and Czuby quarters. The main principle of the landscape planners was to create the system of greenery that would join the green areas between the block of flats with the areas of district gardens and the quarter park. At first, the surface of the quarter park was supposed to be 57 hectares $^{35}$. The space dedicated to the park complex was former agriculture areas with field plantings and the rest of old orchards. Taking into account existing plantings, the main principle of space organization was the park with irregular forms of high greenery and low greenery, which were to be included into the greenery of the residential entities "penetrating" into the individual areas between blocks of flats and respecting characteristic topography of the area. The physiography of the area was particularly emphasized. The area of the district park was the area where it was forbidden to change the topography. Introduced greenery was only to underline its natural landscape. It was supposed to be landscape park; intensive use of the space was possible only in close neighborhood of the buildings. For this reason, high greenery was introduced only in higher grounds of the district park in order to create a kind of acoustic isolation - the buffer and shield for residential buildings. The valley plan included the low- and medium-height greenery. The space of the park was defined in the development plan as a space for passive relaxation taking into account the rule of division of the areas depending on the age groups of the users ${ }^{36}$. The program of recreation took into account the principle of division of the areas and their equipment depending on the age of the users. ${ }^{37}$ The key element of the project was to link designed quarter park with the north districts of LSM quarter (Juliusz Słowacki's district, Adam Mickiewicz's district, Piastowskie district). The link with south communication tract of the district park was the route along the district centre for culture with the small valley between the residential districts of Konopnicka and Sienkiewicz led farther by central park and opposite hills to Rury railway station and Stary Gaj forest. Zygmunt Krasiński's district was linked with the quarter park with the pedestrian lane through Henryk Sienkiewicz's district. The lane joining the south districts with planned sport centre by Tomasza Zana Street was supposed to be led parallelly to the main lane of the central park (direction

33 Apart from this, it was planned to make so-called "special gardens" - woodlot of the Museum of Majdanek (54 hectares) and new area of botanical garden with zoo of 20-40 hectares and Lublin cemeteries. It was planned to partly remove allotments in favour of new areas of greenery taking into account proportional increase of their surface depending on the number of residents, after: Urban Planning Office M. Z. A. B. in Lublin, General Urban Spatial Development Plan of Lublin, Lublin 1957, VII Greenery and sport, C 56, C 59, C 60.

34 Local Plan of General Spatial Development Plan of Lublin of the second part of the Rury quarter of L.S.M: H. Sienkiewicz's district, M. Konopnicka's district in Lublin, A.2 text of the plan, main planner eng. MSc. Arch. Janusz Link, senior assistant eng. MSc. Arch. Mirosław Załuski, landscape planner eng. MSc. Euzebiusz Maj, 1969-1971, the archive of the Lublin Town Hall, p. 3

35 Ibid., p. 4

36 Ibid., p. 7

37 lbid., p. 7 
Helenów - Bystrzyca - Wrotków) and according to the plans it was to run across in two variants - by the north border of the central park and by the districts. ${ }^{38}$ (Fig. 7A, 7B, 8)
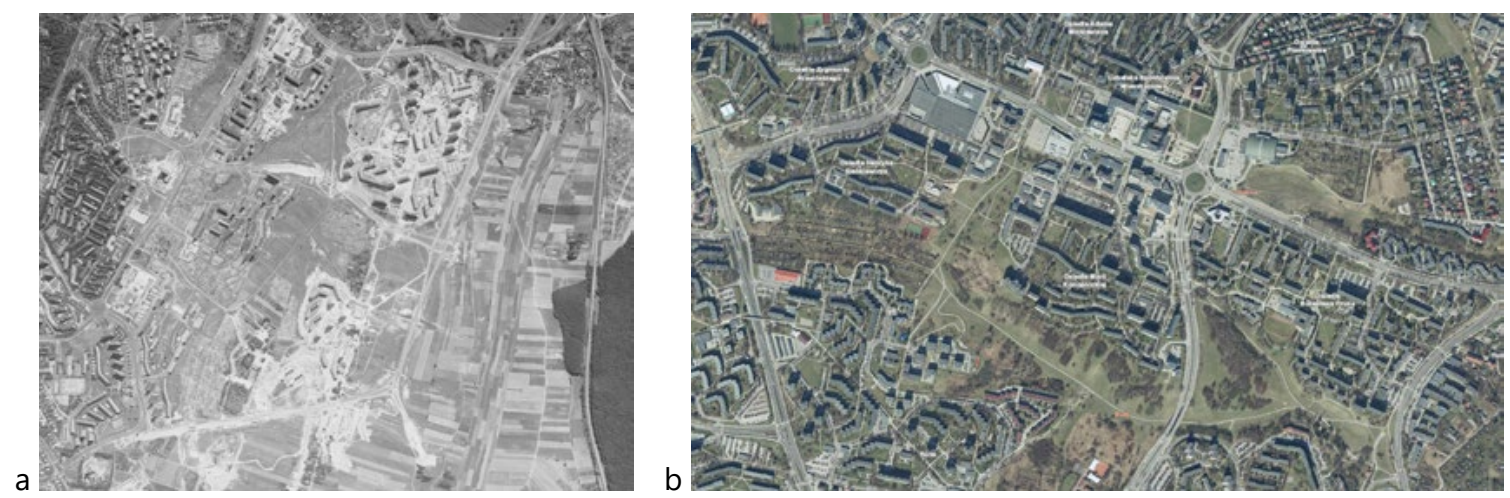

Fig. 7. A - The 1980s, the aerial photography of the Rury district park, the archive of KAUiPP, Lublin University of Technology, B - Current shape, Source: geoportal, accessed 10.10.2018
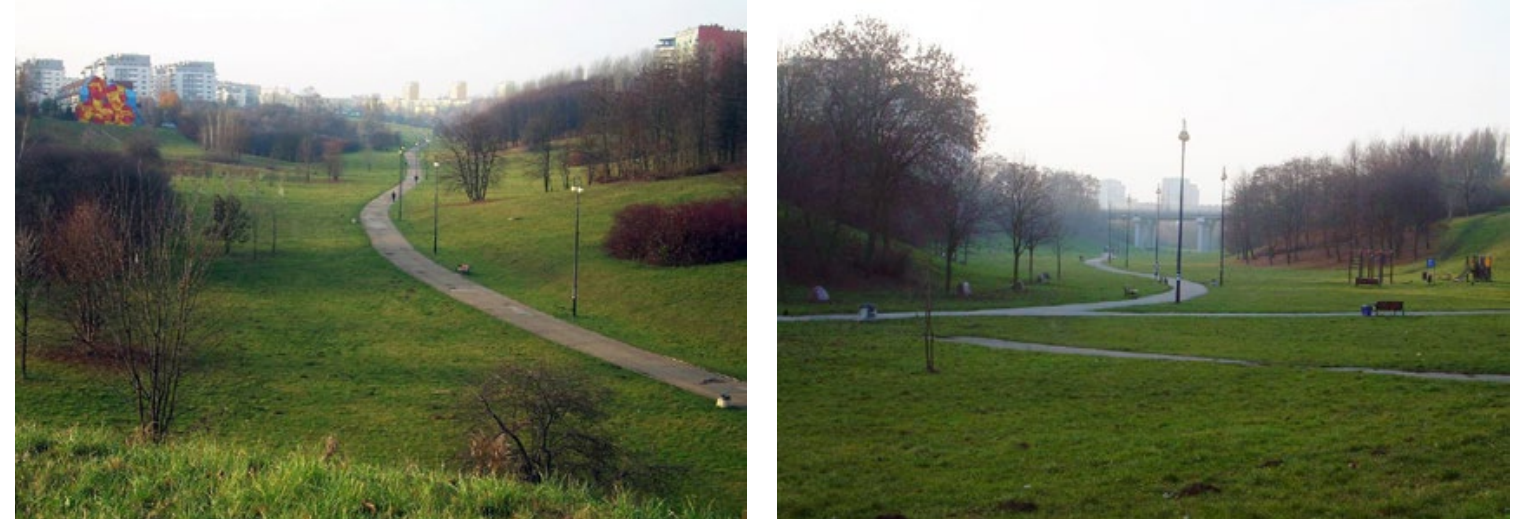

Fig. 8. Rury Park, the main communication tract along the dry valley, author's own photography

\section{Summary}

The complexes of the districts of the Lublin Housing Collective LSM were the examples of unique way to plan the space and architecture for non-anonymous users. It's important to emphasize that it was made in the 2nd half of the 20th century, when introduced norms and standards were harmful to the quality of the buildings and their surroundings. Adam Mickiewicz's and Juliusz Słowacki's districts were the example of successful personalized space accessible for everyone, with a large ratio of greenery and omnipresent art in the form of sculptures, murals and mosaics being the legacy of Lubelskie Spotkania Plastyczne - the initiative of artists to decorate the districts with the works of art. Romuald Dylewski - the director of Lublin Urban Planning Office in 1956-1974 said that he hoped that "each of (...) subsequent districts (after the Mickiewicza and Stowackiego district - editorial note) will be better than the others. According to the rule that practice makes perfect". ${ }^{39}$ Unfortunately, the era of pre-fabricates and the reduction of the construction budget left a negative mark on the residential complexes built by LSM in the 1970 s. The green architecture ${ }^{40}$ designed by next architects and urban planners, 
which was supposed to constitute the common element of seven districts of LSM, was realized only partly. In the 1990s the idea of the system of green boulevards and accessible to all district park was completely abandoned, because of the new buildings constructed along Tomasza Zana Street. Many investments including the controversial project of central complex ${ }^{41}$ being the heart of interregional services, which was planned in the centre of the district for around 30 years, were not realized for technical and financial reasons, and the rest of area was devoted for residential buildings and large-surface service and office buildings.

\section{Literature}

[1] Abramson D., Participation in postsocialist hosuing, 1985, Harvard University,

[2] Adamiec P., Trzaskowska E., Rewitalizacja osiedlowych terenów zieleni - metody pracy na przykładzie Lubelskiej Spótdzielni Mieszkaniowej, Krajobrazy Lublina - Osiedla Mieszkaniowe, 2015,

[3] Architektura, miesięcznik, roczniki 1959, 1960,

[4] Chatres'd Athens,

[5] Dąbkowski H., Karaś R., Lubelska Spółdzielnia Mieszkaniowa, Ed.; Centrala Rolnicza Spółdzielni "Samopomoc Chłopska”. Zakład Wydawnictw. 1968,

[6] Denys M., Źródła idei i drogi powstania Lubelskiej spółdzielni Mieszkaniowej, in: 50 lat Lubelskiej Spółdzielni mieszkaniowej,

[7] Gawarecki H., Gawdzik C. Lublin. Krajobraz i architektura, Warszawa, 1964,

[8] Gawarecki H., Gawdzik C., Ulicami Lublina, Lublin, 1976,

[9] Gnot L., 1987. Nowy Lublin, Osiedla Lubelskiej Spótdzielni Mieszkaniowej, Lublin, Informator LSM", 2009, nr 60,

[10] Lubelska Spółdzielnia Mieszkaniowa, ZWCRS, Warszawa 1968,

[11] Hansen O., Forma Otwarta, Przegląd Kulturalny,1959,

[12] Hansen O., Nauczyciel, "Architektura” ,1966, nr 12,

[13] Jezierski B., Zespót centralny dzielnicy Rury, in: Miesięcznik Osiedle, gmina, region, kraj, Miasto 88, 9/ September,

[14] Kociuba D., Lublin, Rozwój Przestrzenny i funkcjonalny od średniowiecza do wspótczesności, Wydawnictwo Adam Marszałek, Toruń 2011,

[15] Pastuszko I., Nowoczesne planowanie przestrzenne na przykładzie planu ogólnego rozwoju Lublina, w Annales Universitatis Mariae Curie - Skłodowska, Lublin - Polonia, sectio L, vol. XV, 2, 2017,

[16] Pracownia Urbanistyczna M. Z. A. B. w Lublinie, Ogólny Plan Zagospodarowania Przestrzennego Miasta Lublina, Lublin 1957, VII Zieleń i sport, C 56, C 59, C 60,

[17] Przesmycka E. ,Sosnowska M., Przeobrażenia układów zieleni osiedlowej na przykładzie zespołu im. Adama Mickiewicza Lubelskiej spótdzielni Mieszkaniowej, Czasopismo techniczne Materiały 1957-1967, 8/6, I/6, F. Haczewski, Zasady projektowania osiedla im. Adama Mickiewicza w Lublinie, the archives of LSM in Lublin

[18] Przesmycka E., Sosnowska M., Przeobrażenia układów zieleni osiedlowej na przykładzie zespołu im. Adama Mickiewicza Lubelskiej Spótdzielni Mieszkaniowej, 2007, Czasopismo Techniczne 10 Architektura z. 5-A, 73-75.

[19] Przesmycka E., Sosnowska M., Przeobrażenia krajobrazu osiedli Lublina, Teka Komisji Urbanistyki, Architektury i Studiów Krajobrazowych, OL PAN, 2013, IX/4

[20] Przesmycka N., Dmitruk M., Rewitalizacja przestrzeni międzyblokowych inicjatywa spoteczna w procesie rewitalizacji na przykładzie wybranych przestrzeni w Lublinie, typescript,

[21] Przesmycka, E., Sosnowska M. 2010. Stan zachowania przestrzeni publicznych osiedli mieszkaniowych z lat 50 XX w. na przykładzie Lublina. Teka Kom. Arch. Urb. Stud. Krajobr. - OL PAN, 2010,

[22] Trzaskowska E., Adamiec P., Przemiany w obrębie zabudowy wielorodzinnej. Osiedla mieszkaniowe po dwudziestu dwóch latach transformacji (LSM). Warszawa 2014,

[23] Trzaskowska E., Adamiec P., Park Miejski, Jako Forma Ochrony Suchych Dolin Lublina. Wąwozy i suche doliny Lublina Potencjat i zagrożenia, 2014,

[24] Wąwozy i suche doliny Lublina potencjat i zagrożenia, pod redakcją Ewy Trzaskowskiej, Lublin, 2014,

41 The central complex was built for around thirty years. Planning works started in 1968. In 1983 the plan was verified, and as a result the extension of the centre for cultureand location of non-intrusive industries was cancelled and the areas used for relaxation garden planned originally was dramatically decreased. Instead, this area was used for residential purposes with garages and commercial - service buildings, after: B. Jezierski, Zespót centralny dzielnicy Rury, in: Miesięcznik Osiedle, gmina, region, kraj, Miasto 88, 9/ September, p. 9 
[25] Żurkowska M., Planowanie przestrzenne jako instrument ochrony systemu przyrodniczego dolin rzecznych i suchych dolin w Lublinie, w: Wąwozy i suche doliny Lublina potencjat i zagrożenia, pod redakcją Ewy Trzaskowskiej, Lublin, 2014.

\section{Sources}

[26] Local Plan of General Spatial Development Plan of Lublin - the text of the plan, 1986

[27] Materials 1957-1967, 8/6, I/6, F. Haczewski, Zasady projektowania osiedla im .Adama Mickiewicza w Lublinie, the archive of Lublin Housing Collective LSM,

[28] Miejscowy Szczegółowy Plan Zagospodarowania Przestrzennego drugiej części dzielnicy „Rury” osiedla L.S.M. im. H. Sienkiewicza, im. M. Konopnickiej w Lublinie (Local Detailed Spatial Development Plan of the second half of the Rury quarter - H. Sienkiewicz's and M. Konopnicka's districts), A.2 the text of the plan, Main planner Arch. Janusz Link, Msc. Eng. senior assistant, arch. Mirosław Załuski, Msc. Eng., landscape planner Euzebiusz Maj, Msc. Eng. 1969-1971, the archive of the Lublin Town Hall

[29] Nowy Lublin Osiedla LSM, Lubelska Spótdzielnia Mieszkaniowa, Wojewódzki Ośrodek Informacji Turystycznej w Lublinie, Lublin, 1977

[30] Ogólny Plan Zagospodarowania Przestrzennego Miasta Lublina (General Spatial Development Plan of Lublin), 1956-1965, D III - housing, C14, the archive of the Lublin Town Hall

[31] Ogólny Plan Zagospodarowania Przestrzennego Miasta Lublina, 1956-1965, D III - mieszkalnictwo, C14, the archive of the Lublin Town Hall

[32] The Act no. 627/XXIX/2009, of the Lublin City Council of 19 February 2009 regarding the status of Rury quarter

[33] Archiwum Katedry Architektury, Urbanistyki i Planowania Przestrzennego, Politechniki Lubelskiej - zdjęcie lotnicze (LSM) z 1985r.

[34] Urban Planning Office M. Z. A. B. in Lublin, General Urban Spatial Development Plan of Lublin, Lublin 1957, VII Greenery and sport, C 56, C 59, C 60

\section{Internet sources}

[35] Szlachetka M., Jak budowała się dzielnica LSM „Panie Inżynierze to sa przecież góry”, in: Kurier Lubelski, https://plus.kurierlubelski.pl/jak-budowala-sie-dzielnica-Ism-panie-inzynierze-to-sa-przeciez-gory/, accessed 10.10.2018

[36] http://lublin.wyborcza.pl/lublin/1,48724,21010782,dzialkowcy-nie-chca-oddac-ogrodkow-pod-wielki-staw-maja-racje. html, accessed 10.10.2018

[37] www.geoportal.pl, accessed 10.10.2018 